\title{
From bodies to bones: death and mobility in the Lake Titicaca basin, Bolivia
}

Scott C. Smith ${ }^{1, *} \&$ Maribel Pérez Arias ${ }^{2}$

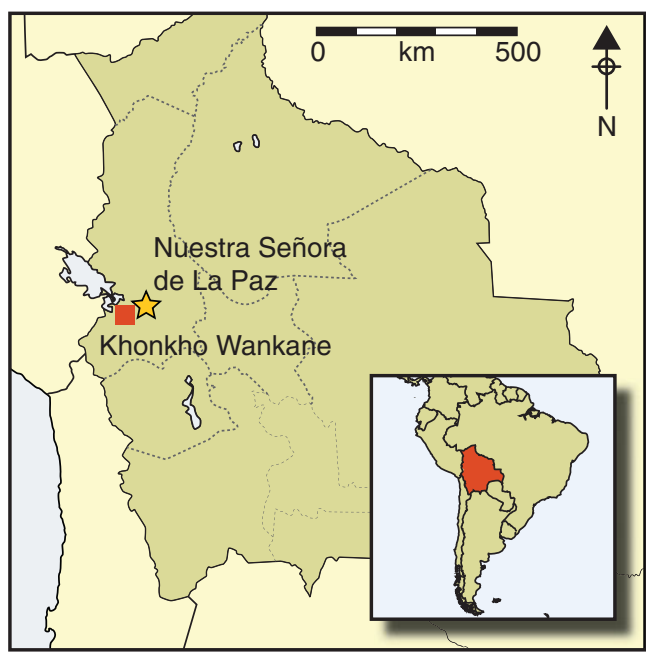

Keywords: Bolivia, Titicaca basin, Late Formative, mortuary ritual, quicklime, llama caravans
Disposal of the dead in early societies frequently involved multiple stages of ritual and processing. At Khonkho Wankane in the Andes quicklime was used to reduce corpses to bones in a special circular structure at the centre of the site. The quicklime was obtained from solid white blocks of calcium oxide and was then mixed with water and applied to disarticulated body parts. A few plaster-covered bones were recovered from the structure but most had been removed from the site, possibly by itinerant llama caravans. Thus, Khonkho Wankane was a ritual centre to which the dead were brought for processing and then removed for final burial elsewhere.

\section{Introduction}

Approaches to the archaeological study of mortuary practices and ritual have moved away from perspectives that conceptualise the living and the dead in opposition to one another. These approaches, which Rakita and Buikstra (2005: 8-9) refer to as "ancestral-descendent", highlight the ways in which the dead play an active role in social life, influencing ceremonial, political and economic dynamics (Buikstra \& Charles 1999; Parker Pearson 1999; Adams \& King 2011; cf. Whitley 2002). In the Andes, these insights find strong support in ethnographic, ethnohistoric and archaeological studies (Dillehay 1995; Isbell 1997; Arnold \& Hastorf 2008). Hastorf (2003) in particular has discussed the active role played by the dead in social and political life during the Middle Formative period (800-200 BC) in the southern Lake Titicaca basin (Figures $1 \& 2$ ). At the ritual centre of Chiripa, human

1 Department of Anthropology, Franklin \& Marshall College, PO Box 3003, Lancaster, PA 17604-3003, USA (Email: scott.smith@fandm.edu)

2 Department of Anthropology, University of Pittsburgh, Pittsburgh, PA 15260, USA (Email: permaribel@gmail.com)

Author for correspondence 


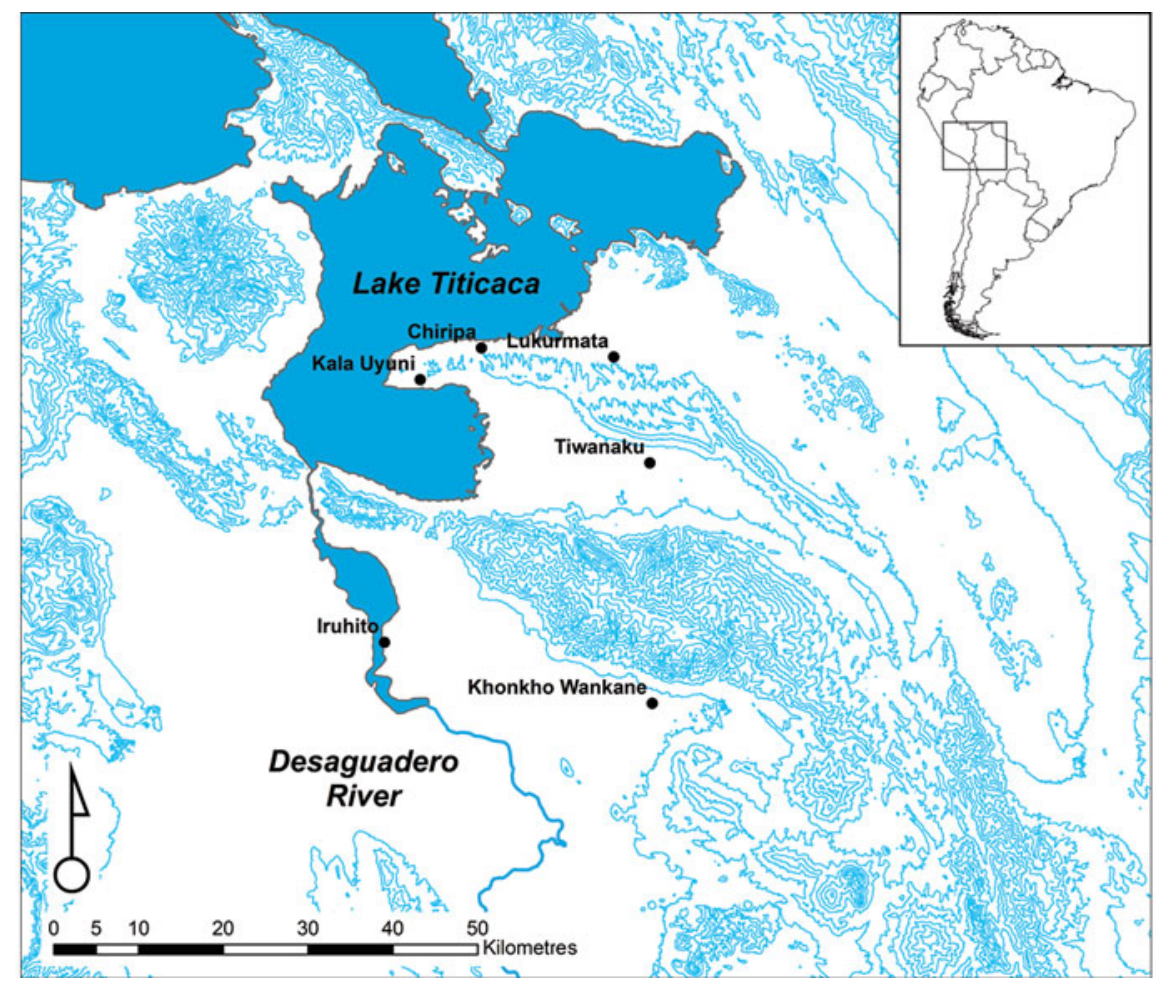

Figure 1. The location of Khonkho Wankane within the southern Lake Titicaca basin.

remains were buried in small structures that surrounded a central enclosure and were accessed periodically for ritual. Hastorf argues that human remains were central to the creation of community. The dead helped to anchor social identity in a collective understanding of the past and embedded lineage in the landscape.

During the subsequent Late Formative period (200 BC-AD 500), however, evidence suggests that community came to be defined differently (Janusek 2008, 2013). New centres replaced their Middle Formative predecessors and were often located further away from Lake Titicaca and nearby rivers. These centres exercised a wider political influence and their development was driven in part by the increasing importance of llama caravans, which circulated animals, people, objects and ideas regionally and inter-regionally (Browman 1978; Núñez Atencio \& Dillehay 1995 [1979]; Bandy 2005). How did the social importance of the dead change during this time of increased mobility and population fluctuation? We explore this question through an analysis of early mortuary ritual at one of the most important Late Formative period centres in the southern Lake Titicaca basin, a site called Khonkho Wankane (Figure 1). A process is highlighted whereby human remains were processed from bodies to curated bones. In contrast to the evidence from Chiripa, where human remains anchored community to a particular location in the landscape, specialists at Khonkho Wankane may have served a mobile population of caravan drovers from distant regions through the creation and curation of portable relics. After a brief introduction to the region and site, we describe the results of the excavation of one particular early structure at Khonkho Wankane and 
detail the fascinating assemblage associated with it, interpreting it in terms of mortuary ritual. This is given additional strength through a brief discussion of the iconography

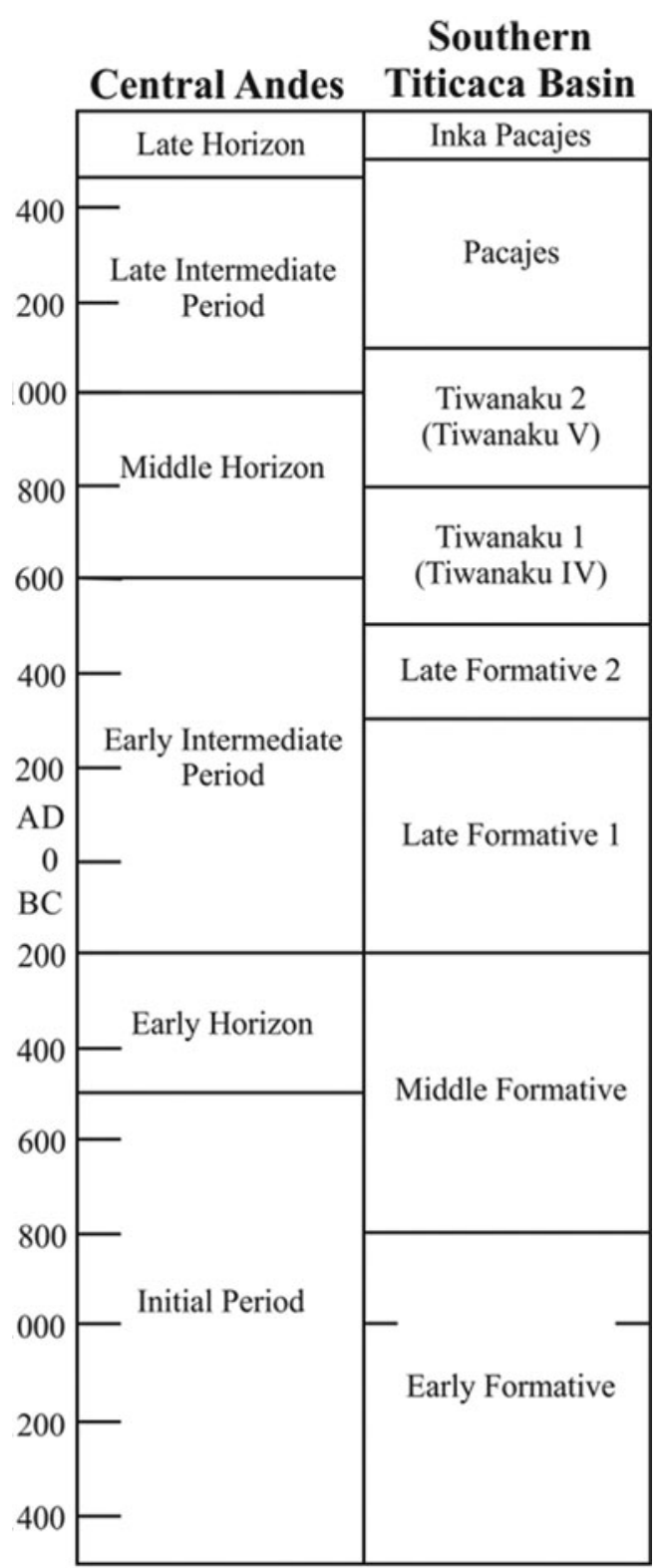

Figure 2. Chronological chart for the Central Andes and the southern Lake Titicaca basin. present on the carved monoliths from Khonkho Wankane. We conclude with a discussion of the significance of this argument for our understanding of social dynamics during the Late Formative period and how these patterns differ from earlier Middle Formative period traditions.

\section{The Lake Titicaca basin and Khonkho Wankane}

Khonkho Wankane is located roughly $46 \mathrm{~km}$ south-west of Chiripa and was principally occupied during the Late Formative period, a dynamic time of increasing social complexity when a number of centres were influential, including Khonkho Wankane, Tiwanaku, Lukurmata, Kala Uyuni, Palermo and Kallamarka (see Figure 2) (Janusek et al. 2003; Stanish 2003; Hastorf 2005; Bandy \& Hastorf 2007; Janusek 2008, 2013). By the end of this period, Tiwanaku began to expand in both extent and density of population, consolidating power within the region while at the same time strengthening social hierarchy within the site itself and expanding its influence throughout much of the south-central Andes (Kolata 2003).

Khonkho Wankane was founded during the late first century $\mathrm{AD}$, and there were three broad periods of occupation at the site, referred to as Early, Middle and Late Khonkho (Figures 3 \& 4) (Smith 2009, 2013). The Early Khonkho occupation consisted of eleven circular structures in three sectors of the site. Seven of them are arranged around a central patio, while the other four structures were located to the north and south of this central patio (Figure 4a). During the Middle and Late Khonkho periods significant changes to the spatial organisation of the site included the construction of at least three sunken temples, long compound walls and earthen platforms (Figure $4 \mathrm{~b} \&$ (C) Antiquity Publications Ltd, 2015 

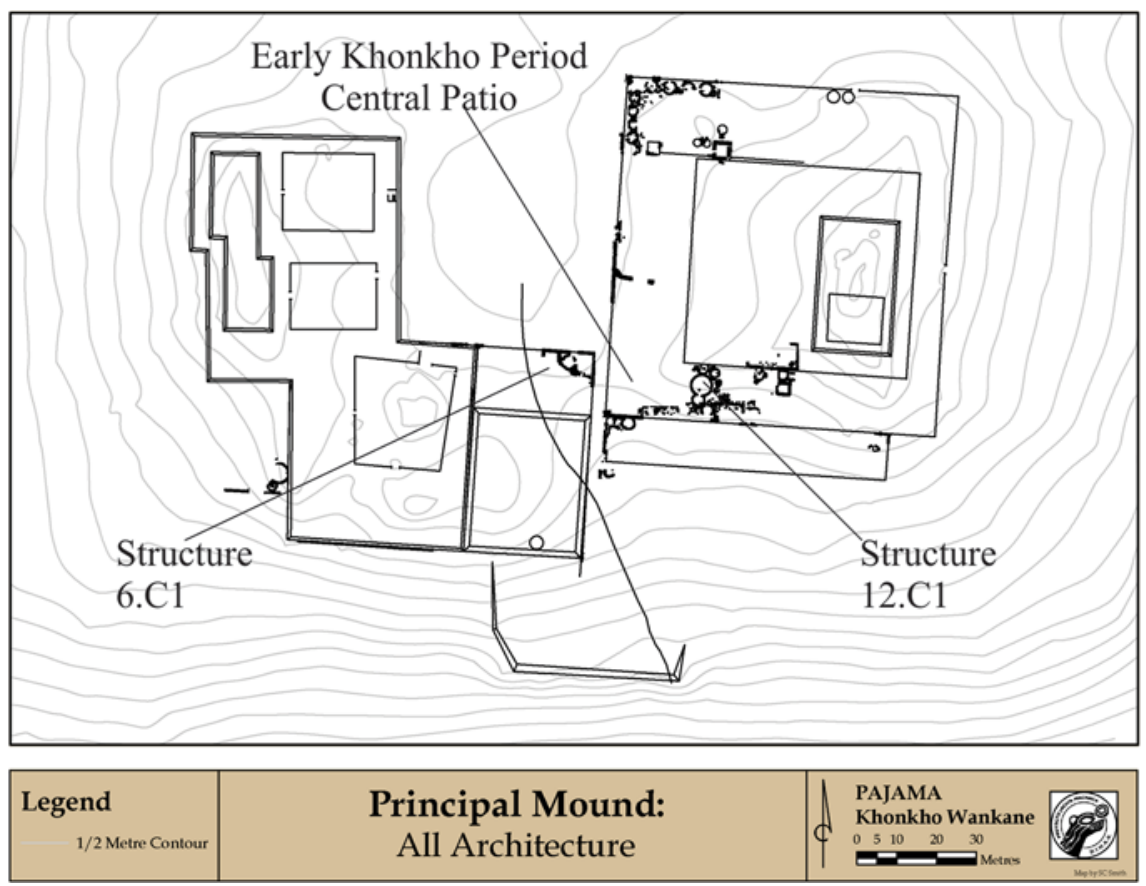

Figure 3. Plan of architecture identified at Khonkho Wankane showing the location of architectural features discussed in the text.

c) (Smith 2009, 2013). By AD 500 the ceremonial core of Khonkho Wankane was largely abandoned (Janusek 2013).

\section{Early ritual and Structure 12.C9}

Our focus here is specifically on the Early Khonkho period and the ceremonial dynamics that anchored the site's growth and influence. The Early Khonkho period circular structures were fairly uniform in size, with most measuring roughly $2.5 \mathrm{~m}$ to $3.5 \mathrm{~m}$ in diameter, but one structure, Structure 12.C9, was significantly larger, measuring $4.9 \mathrm{~m}$ in diameter (Figure 5). This structure also contained a unique and fascinating assemblage (Smith \& Pérez Arias 2007; Smith 2009). Some 972 human bones were recovered, from at least 25 individuals. Most were isolated elements: phalanges, carpals, tarsals, patellae and teeth were particularly prevalent (Smith \& Pérez Arias 2007; Domanska \& Janusek 2008; Janusek 2009). The articulated remains of one hand and one foot were also found (Figure 6). Relatively few long bones or crania were present and at least 14 specimens exhibited cut marks. Analysis of these remains by Domanska indicates that 20 of the 25 individuals represented in the assemblage were adults over 25 years of age (Domanska \& Janusek 2008; Janusek 2009). Most of the bones were covered with a thin, white plaster coating, including the articulated hand and foot, and 23 of the specimens showed evidence of having been painted with red pigment. 
Also associated with this structure were 27 blocks made from a relatively soft, white, chalky material that appeared to be the same material as that covering the human bones

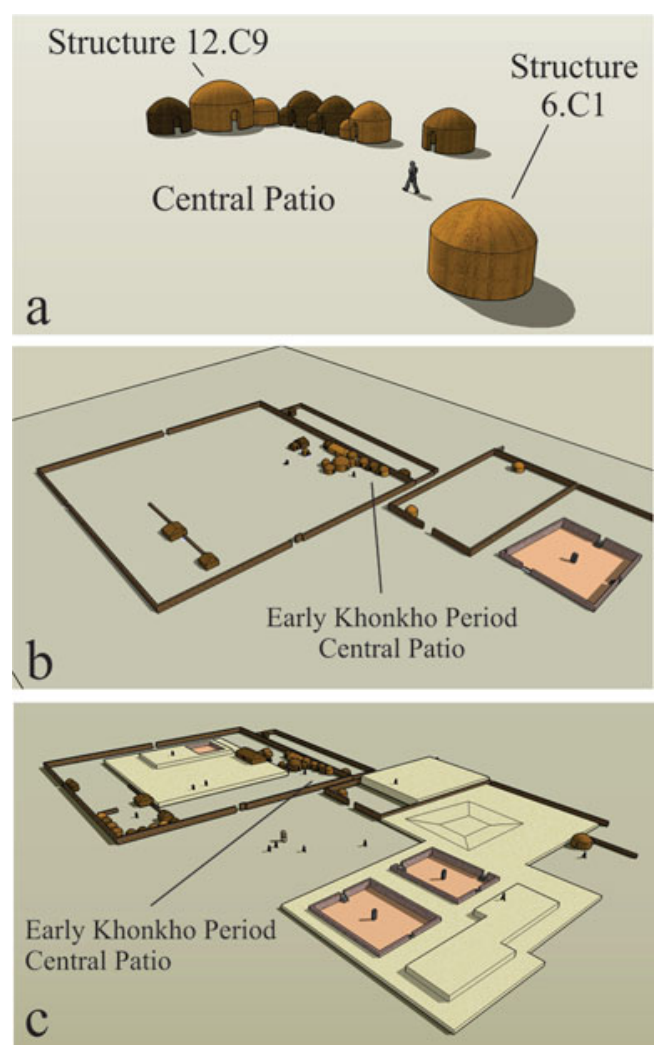

Figure 4. a-c) Reconstructions of the Early, Middle and Late Khonkho-period built environments showing the location of architectural features discussed in the text. For reference, the location of the Early Khonkho-period central patio is indicated in the reconstructions of the Middle Khonkhoperiod (b) and Late Khonkho-period (c) built environments.
(Figure 7a). Nine of these blocks were deposited in two small caches along the northern and eastern interior perimeters of the structure. Blocks such as these are found in different forms and in several contexts at Khonkho Wankane. They are found as solid cubes, cylinders and (most frequently) rectangular blocks, associated with floors or in small caches. In addition to the two caches encountered in this structure, one cache of nine blocks was associated with one of the later sunken temples and another cache of eight blocks was associated with a Middle Khonkho period domestic structure (Figure 7c). These blocks have also been found in burial contexts, sometimes placed beside the head of the interred. Maks Portugal Zamora's 1955 publication of his early excavations at Khonkho Wankane documents one case of this practice and he notes that it is common in burials at the site (Portugal Zamora 1955: 62-67). Our excavations documented one instance of this practice in an infant burial associated with Late Khonkho period architecture (Figure $7 \mathrm{~b}$ ) (Zovar 2006).

Other white blocks are also found with a hole in one side as if they had been perforated and hollowed out (Figure 8a). The perforated blocks are never found in caches but are found in fill and associated with floors. This material is also encountered as concave corner fragments, as if a whole cube had been hollowed out to the extent that it fractured (Figure $8 \mathrm{~b}$ ). These fragments are often found in midden or floor contexts. The perforated blocks and the concave block fragments may be the result of a process whereby the solid blocks were hollowed out to release the white chalky material in powder form. Excavations recovered four worked-bone tools made from llama scapulae and long bones that were covered with what appeared to be the same white material, suggesting that these implements were used to process it (Figure 8c).

White blocks like these are not uncommon in the southern Lake Titicaca basin, and are found at contemporaneous sites including Lukurmata, Tiwanaku and Kala Uyuni. The earliest example was encountered in association with Middle Formative period ceramics,

(C) Antiquity Publications Ltd, 2015 


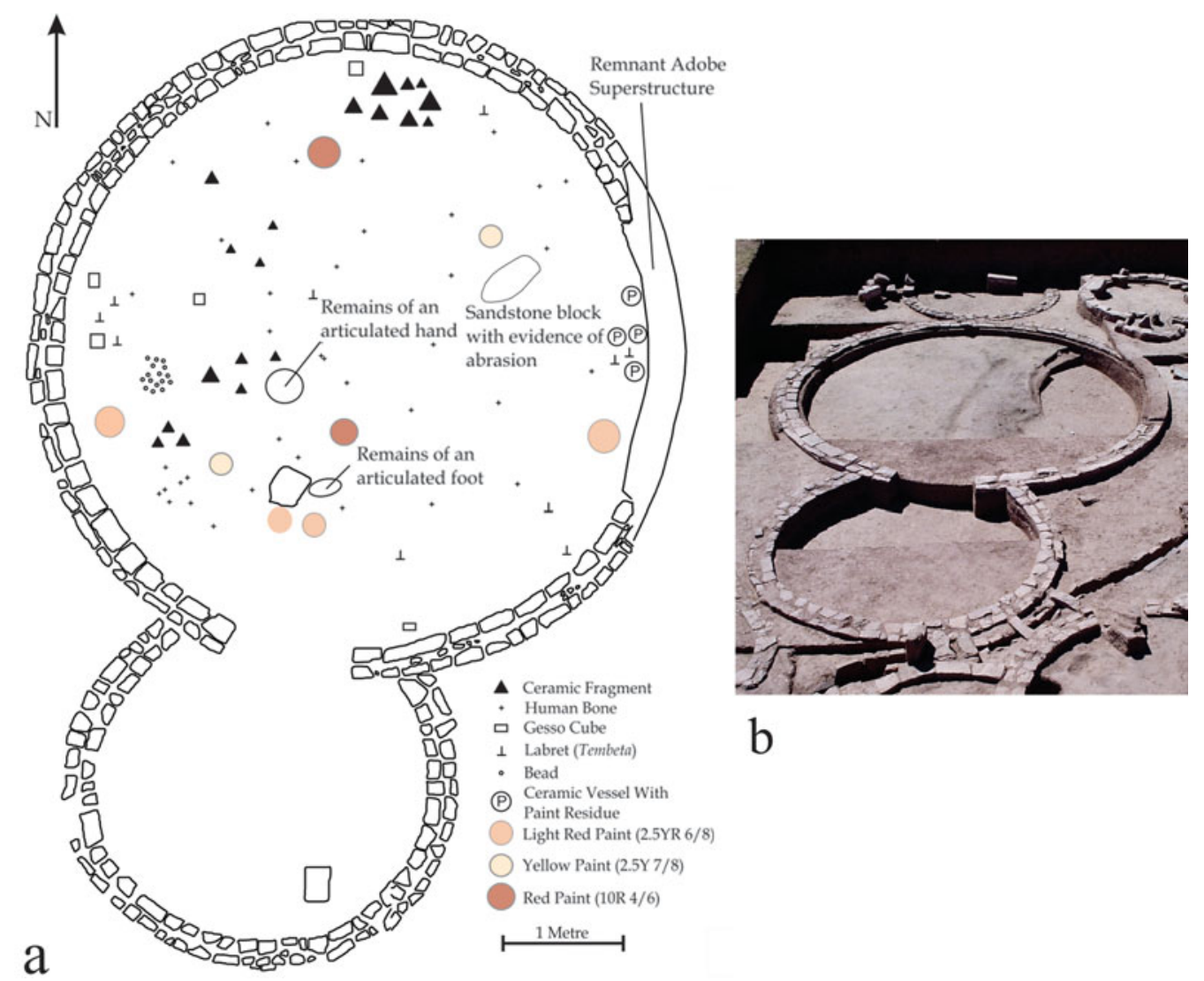

Figure 5. Plan (a) and photo (b) of Structure 12.C9, facing north.

during our recent excavations at the site of Iruhito along the Desaguadero River. These blocks are commonly interpreted as moulds or crucibles for metal working (Bermann 1994:

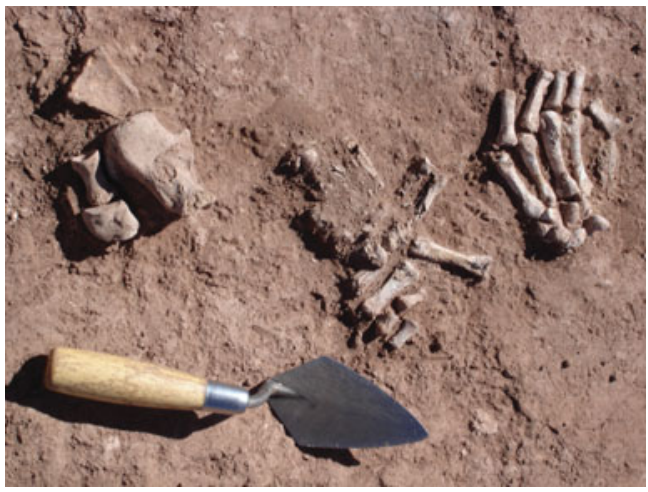

Figure 6. Articulated hand and other skeletal elements discovered on the floor of Structure 12.C9.
73). Working with a sample of similar blocks from Kala Uyuni, Di Hu (2011) analysed their elemental composition using energy-dispersive X-ray fluorescence. She determined that the samples were composed principally of calcium oxide $(\mathrm{CaO})$ - quicklime, or cal viva in Spanish. $\mathrm{Hu}$ further found no evidence that the blocks from Kala Uyuni were used in metal working (Hu 2011: 120). Recently, a sample of the blocks from Khonkho Wankane was similarly analysed using a portable X-ray fluorescence unit by Ryan Williams and John Janusek. Preliminary results indicate that the blocks from Khonkho Wankane are also quicklime. 

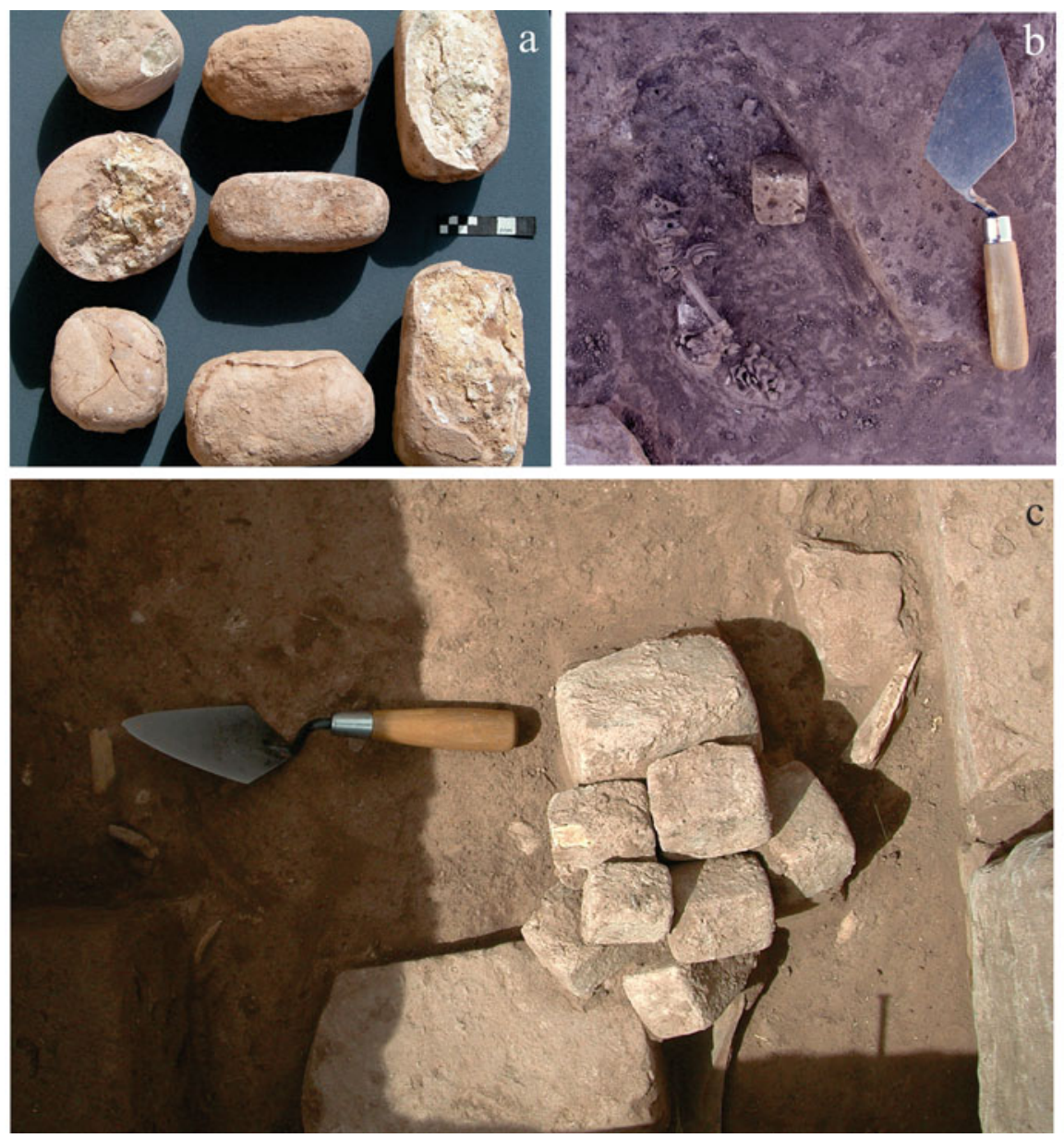

Figure 7. a) Calcium oxide blocks recovered from Structure 12.C9; b) block associated with infant burial; c) cache of stacked blocks.

Calcium oxide is produced through the thermal decomposition of limestone by heating it to between 800 and $900^{\circ} \mathrm{C}(\mathrm{Hu} 2011: 119)$. This process requires the sustained application of heat and may require long firings because the decomposition reaction begins at the surface of the limestone block and slowly proceeds to the core (Kingery et al. 1988). Sustaining these temperatures for long periods of time may have been difficult, a problem which may explain the form of the blocks recovered at Khonkho Wankane and other sites in the region. Smaller blocks and cylinders of limestone would make for a more efficient production process by decreasing the firing time required to produce the quicklime.

To the west of Structure 12.C9, across the central patio, excavators encountered a large hearth that was adjacent but not attached to the westernmost circular structure (Structure 6.C1; Figure 9) (Janusek et al. 2005). This hearth is particularly interesting because, while it was comparatively large, relatively low proportions of ceramic cooking-vessel fragments were associated with it (10 per cent of the ceramic assemblage by weight) compared with the (C) Antiquity Publications Ltd, 2015 
other circular structures surrounding the central patio (26 per cent of the structure ceramic assemblages by weight), and the other contemporaneous structures outside this patio area (51 per cent of the structure ceramic assemblages by weight). Further, when exposing this hearth, excavators noted copious inclusions of what they described as hard, chalky, white clay ranging in length from $10 \mathrm{~mm}$ to roughly $100 \mathrm{~mm}$. It is possible that these inclusions were waste associated with the process of firing cut limestone blocks to produce quicklime. These data may indicate that, in addition to its use for cooking food, the hearth may have also been used as a lime kiln.
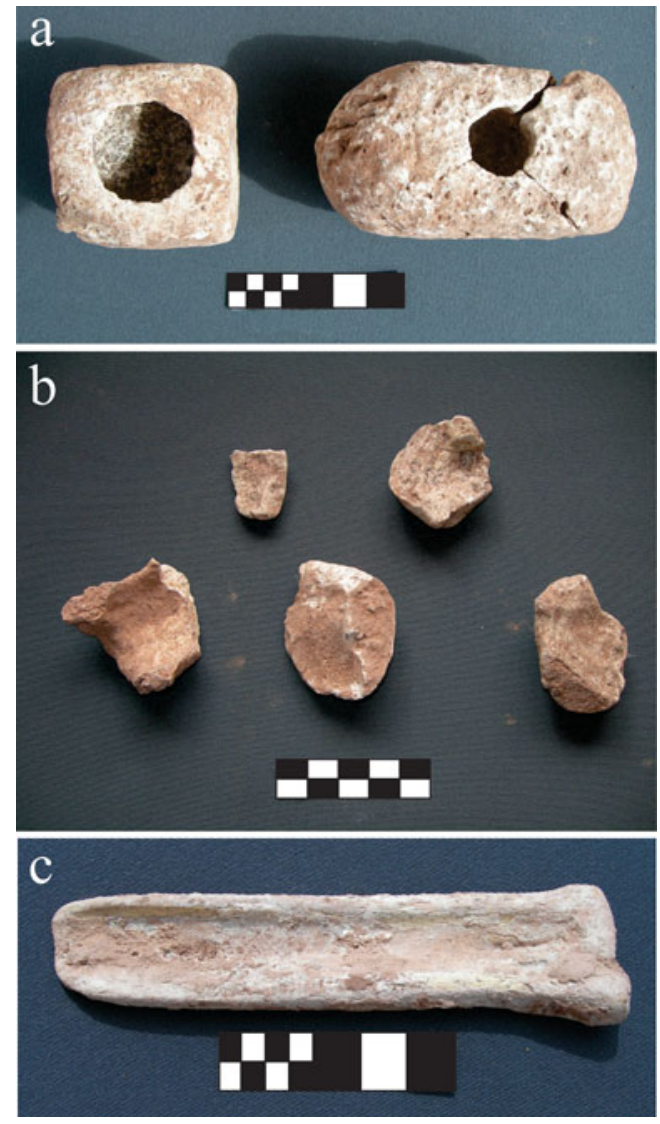

Figure 8. a) Perforated blocks of calcium oxide; b) block fragments; c) worked llama femur coated with white material. were also associated with this surface (Figure 10b) (Smith \& Pérez Arias 2007).

\section{Processing the dead}

The evidence described above indicates that Structure 12.C9 was a specialised space used

by early ritual specialists at Khonkho Wankane to process human remains. The process was
(O) Antiquity Publications Ltd, 2015

by early ritual specialists at Khonkho Wankane to process human remains. The process was
(C) Antiquity Publications Ltd, 2015 combined with water produces calcium hydroxide $\left(\mathrm{Ca}(\mathrm{OH})_{2}\right)$, known as hydrated or slaked lime. During the process of producing hydrated lime, considerable heat is released and the $\mathrm{pH}$ of the mixture increases significantly. Upon exposure to air the hydrated lime mixture absorbs carbon dioxide, causing it eventually to revert back to calcium carbonate $\left(\mathrm{CaCO}_{3}\right)$, creating lime plaster (Schotsmans et al. 2012). At Khonkho Wankane, there is some evidence that hydrated lime was created by mixing the quicklime powder with water. For example, seven complete vessels of varying forms were found on the floor of this structure and several of these had evidence of white plaster coating the interior surface. Additionally, cooking vessel fragments with the same white material on the interior were recovered from this context and others at Khonkho Wankane.

Other vessels associated with the floor of Structure 12.C9 included small bowls with evidence of pigment on the interior (Figure 10a). In addition, there were deposits of red (10R 4/6), yellow (2.5Y 7/8) and light red (2.5YR 6/8) paint on the floor. Eleven labrets, many bone and shell beads of varying sizes, and several grinding stones

Quicklime is alkaline and when 
one in which bodies were disarticulated and then cleaned and curated using the hydrated lime, which, when exposed to air, coated the bones in calcium carbonate or lime plaster.

Intentional defleshing and cleaning of

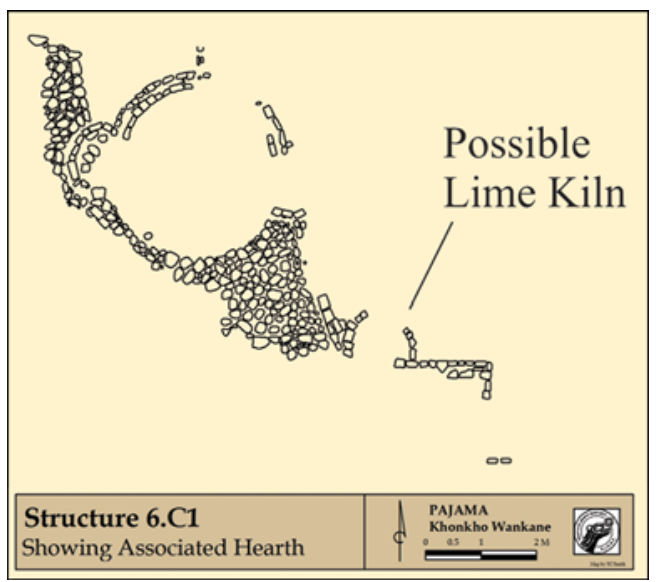

Figure 9. Plan showing location of possible lime kiln.

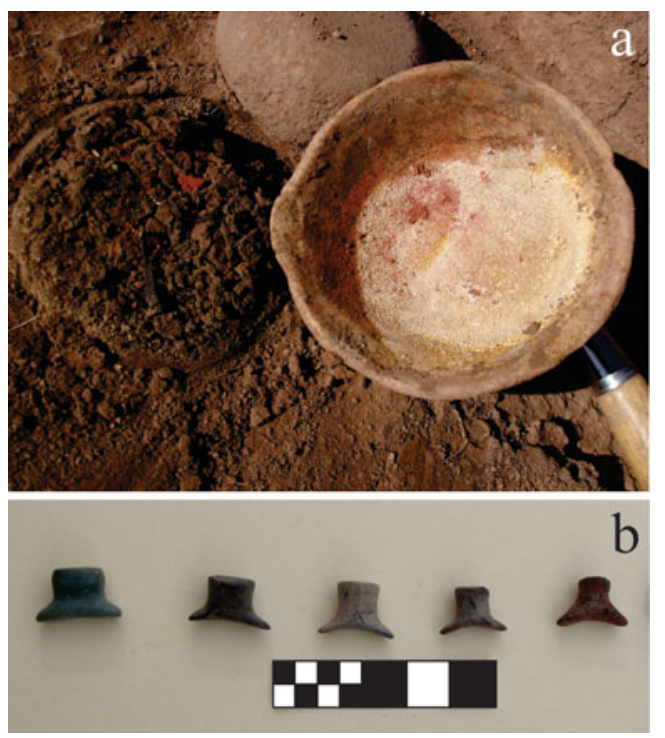

Figure 10. a) Ceramic vessel with pigment; b) sample of labrets recovered from Structure 12.C9. bones is not uncommon in the region. Blom et al. (2003: 442), for example, note evidence of light, repeated cutting on human remains from Tiwanaku 1 period (AD 500-800) occupations at the site of Tiwanaku, which they argue is indicative of post mortem defleshing (see also Blom \& Janusek 2004). It is possible that at Khonkho Wankane the limewater mixture was used to help deflesh and clean the bones. While quicklime powder is a desiccant and would actually preserve human flesh (Schotsmans et al. 2012), there is some evidence to suggest that hydrated lime helps to break down and dissolve muscle tissue (Laudermilk 1932: 62). Leather producers use limewater mixtures called 'lime liquors' to remove hair and fats from specimens in a process called liming (Proctor 1903). The solvent action of the hydrated lime increases when the temperature of the limewater mixture is increased (Proctor 1903: 127). In Bolivia, present author MPA has observed the use of heated limewater mixtures to remove flesh from bones in order to create comparative collections and specimens for medical and veterinary training. At Khonkho Wankane, the presence of ceramic cooking vessels with white plaster coating the interior may suggest that specialists heated limewater, possibly to increase its ability to break down muscle and fat.

This helps to explain the presence of plaster-coated bones in Structure 12.C9. Disarticulated human remains may have been submerged in large cooking vessels containing the heated limewater mixture and manipulated using the llama-bone tools, which explains why they were also covered with the white material. Once the defleshed bones were exposed to the air, the mixture would have formed a thin calcium carbonate coating over the bone. This scenario would help to explain why the calcium carbonate coating is found on the interior of cranial fragments and, especially, covering the articulated hand and foot. In that (C) Antiquity Publications Ltd, 2015 
particular case, it is less likely that the remains were first completely skeletonised and then covered with the plaster precisely because we find them articulated in situ. Additionally, the plaster coating gave them a bright white colour, possibly as a way of enhancing or revealing the essence of the bone itself, similar to the Andean metallurgical processes described by Lechtman (1984). The presence of painted bones, small bowls with pigment on their interior, and deposits of pigment on the surface of the structure suggests that one part of this process involved painting bones. Portugal Zamora's (1955) early excavations at Khonkho Wankane exposed a burial with a red-painted femur.

Whilst there is evidence of painted bones at Khonkho Wankane, no bones coated in white plaster were found in any other context, including burials. The specimens processed at Khonkho Wankane may have been removed from the site after processing. Further, we suggest that the deceased may have been specifically brought to Khonkho Wankane for this specialised ritual from surrounding areas, perhaps by llama caravan. Excavations on peripheral mounds surrounding the site show evidence of periodic occupation and abandonment in the form of thin superimposed floors and ephemeral hearths (Ohnstad 2007). No permanent architecture was documented at these peripheral mounds. Additionally, Gasco and Marsh (2013) identify a population of very large llamas in the faunal assemblage from Khonkho Wankane. Drawing on analogy with modern herd management practices, they suggest that these llamas were castrated, possibly for use in caravans (Gasco \& Marsh 2013: 11). Kelly Knudson (forthcoming) conducted isotope analysis on a variety of bone and tooth samples from Khonkho Wankane, including two samples from Structure 12.C9. Both samples have strontium isotope signatures outside the range for the southern Lake Titicaca basin, indicating that the individuals processed in this structure did not live near this region during dental enamel formation.

This suggests that mobile populations visited Khonkho Wankane periodically, possibly with llama caravans, for rituals involving the processing of human remains that were then removed from the site when the visitors departed. That may explain the high frequency of smaller bones such as teeth, carpals, tarsals, phalanges and patellae in Structure 12.C9. These might have been deposited when bodies were processed into bones, and the larger long bones, crania and ribs were removed from the site. Such a process may also help to explain the high frequencies of decorative adornments such as labrets and beads. They too might have arrived at the site with the bodies and been left behind when the bodies were transformed into bones.

\section{Representations of the process}

There are four carved sandstone monoliths at Khonkho Wankane, and an analysis of their iconography provides insight into the mortuary process described above (Ohnstad 2011, 2013). Figure 11 shows the Jinchun Kala monolith, which was likely erected sometime after AD 150 (Ohnstad 2013: 65) and probably after the process described above was already well established. The back and sides of the monolith seem to portray individuals in movement (Figure 11b) (Ohnstad \& Janusek 2007; Ohnstad 2011, 2013). Moreover, these individuals appear to move up the back of the monolith with flesh and down the sides partially defleshed, with the ribs portrayed as exposed. This may be a depiction of the 

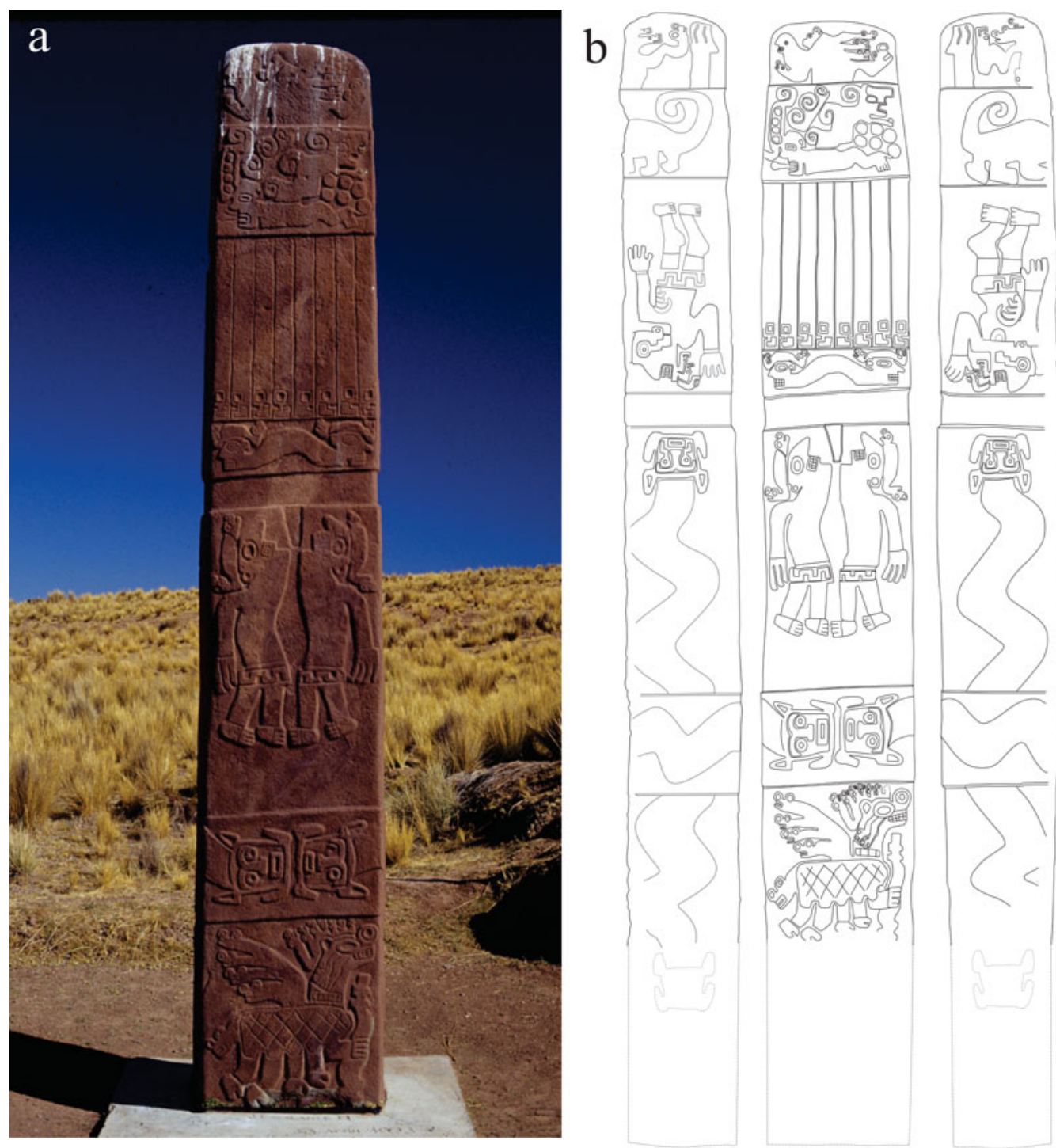

Figure 11. a) Jinchun Kala monolith from Khonkho Wankane (photo courtesy of John Janusek); b) drawing of Jinchun Kala monolith (drawing by Arik Ohnstad and Jenni Ohnstad).

process of producing bones that we have associated with Structure 12.C9. Human remains enter Khonkho Wankane with flesh and leave as bone. The top panel of this monolith portrays a complex and somewhat abstract scene, in which the individuals with flesh seem to be approaching, and the excarnated individuals seem to be departing (Figure 12a \& b). It is possible that this is a depiction of the stacked caches of quicklime blocks and cylinders (compare with Figure 7c). Note the spirals associated with these blocks, possibly depicting the gas released when water is added to quicklime. Additionally, the top panel portrays a bean-like element that, in light of the identification of the blocks as quicklime, could (C) Antiquity Publications Ltd, 2015 

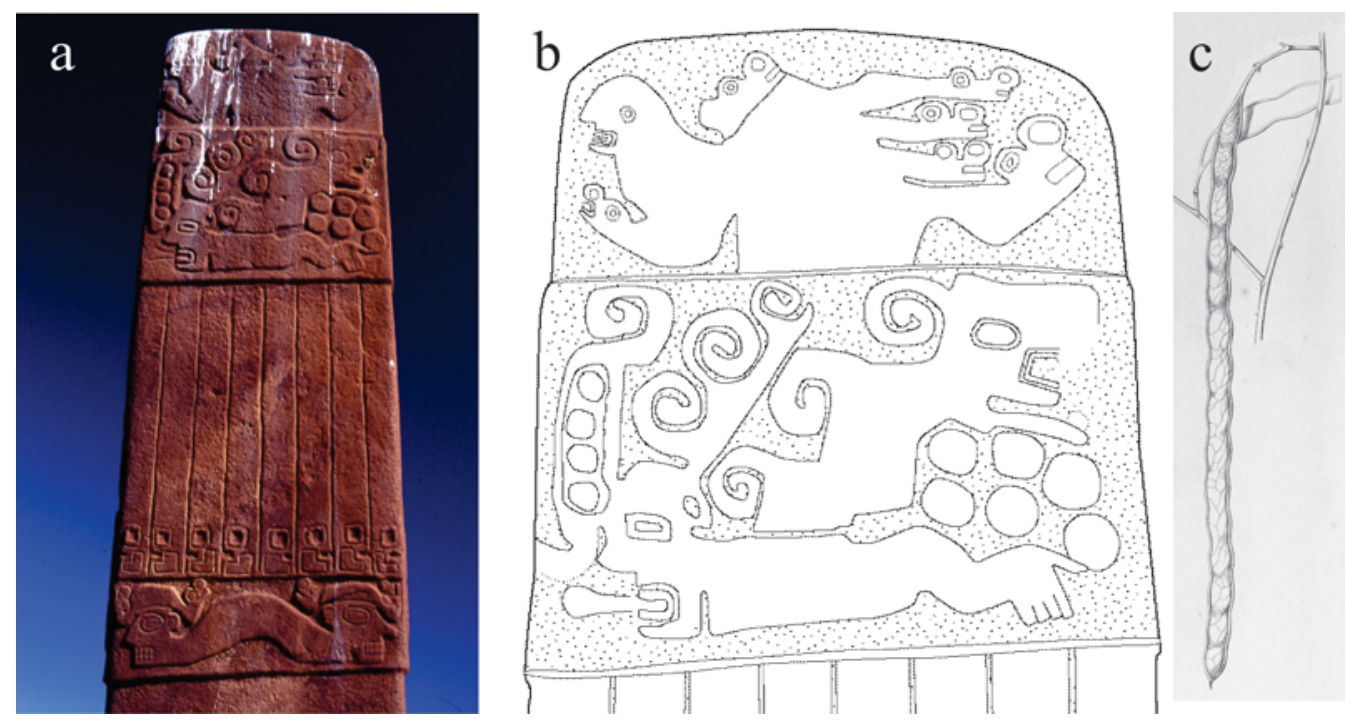

Figure 12. a) Photo and b) drawing of the top panel of the Jinchun Kala monolith (photo courtesy of John Janusek and drawing by Arik Ohnstad and Jenni Ohnstad); c) Anadenanthera colubrina or vilca seed pod (Martius 1876: tab. 76). Image adapted from Missouri Botanical Garden (http://www.botanicus.org). Licensed under the Creative Commons Attribution-Noncommercial 2.5 licence.

be a representation of Anadenanthera colubrina or vilca, which was commonly used in the Andes to produce hallucinogenic snuff (Knobloch 2000; Torres \& Repke 2006) (Figure 12c). Modern indigenous communities in the Orinoco basin of Venezuela and Colombia produce the hallucinogen by removing the seeds from the pod, grinding them and mixing them with a lime mixture produced from calcined shell (Torres \& Repke 2006: 64-70). In addition to its use in the process of cleaning and curating bones, it is possible that the quicklime was mixed with ground vilca to produce hallucinogenic snuff. Snuff paraphernalia, including trays, tubes and spoons, have been encountered in archaeological contexts in Bolivia, Peru, Chile and Argentina (Llagostera M. 1995; Torres \& Conklin 1995; Torres \& Repke 2006: 57-60). Similarly, it is possible that the quicklime was consumed with coca (Erythroxylum coca); today, indigenous groups chew coca with alkaline substances to enhance the analgesic effects of the plant.

\section{Discussion}

The evidence suggests that during a time of heightened movement and circulation, Khonkho Wankane was propelled to prominence in part because of a ritual process of preparing human remains for a mobile agropastoral population. Ritual specialists may have transformed human remains by disarticulating them, and then cleaned and curated them using heated limewater mixtures made from quicklime blocks that were fired at the site. It seems clear that the quicklime blocks were associated with the dead at Khonkho Wankane, particularly given that these blocks are also found in burials, placed next to the head of the deceased. The reaction produced by adding quicklime to water is a violent one, where heat is produced and gas is released. This would have been quite an impressive sensory experience. Modern 
indigenous communities in Bolivia conceptualise smoke, gas and mists as ways in which offerings are transmitted to the supernatural realm (Arnold \& Hastorf 2008). Similarly, the visceral, gaseous process of cleaning human remains to produce plastered bones may have conveyed the deceased to the otherworldly realm. Additionally, the quicklime may have been chewed with coca and mixed with ground vilca to produce a hallucinogenic snuff that could have formed an integral component of a ritual designed to shepherd the dead into the afterlife.

This process seems to represent a shift from earlier Middle Formative modes of integrating the dead into social life. At Chiripa, important individuals were buried in designated places surrounding ritual enclosures. During later iterations of this practice, a series of small stone structures were built in a ring surrounding a sunken enclosure. These structures all contained multiple burials, and there is evidence to suggest that the burials were periodically accessed, perhaps for rituals involving people gathered in the enclosure. Hastorf (2003) has argued convincingly that this mortuary pattern reflects the creation of group cohesion and also increasing hierarchy. These processes were tied to the memorialisation of the particular lineages buried in this central ceremonial space, and the exclusivity of restricted access to the burial structures.

The mortuary evidence discussed here from the subsequent Late Formative period at Khonkho Wankane suggests a break from Middle Formative period traditions. While the continued social importance of the dead is evident in the careful processing and curation of human remains at Khonkho Wankane, these curated remains were not buried at the site, as they had been at Chiripa. The evidence reviewed here indicates that human remains were brought to the site for processing and then removed, probably by periodic llama caravans. Rather than anchoring lineage to the ceremonial centre, curated remains travelled with mobile populations of caravan drovers. We submit that the ancestors were still crucial to the definition of community but that community was conceptualised in very different terms during the Late Formative period and may have united people who were dispersed over much larger regions.

This research responds to recent studies encouraging us to expand the spatial and temporal scales at which archaeologists analyse mortuary ritual. For example, Ashmore and Geller suggest that archaeologists might usefully consider "mortuary space as an analytical domain embracing scales ranging from within individual interments and other forms of disposition, to distributions of burial sites across the landscape" (Ashmore \& Geller 2005: 82; original emphasis). Whereas archaeologists typically have access to the final resting point of mortuary remains, the data from Khonkho Wankane give us a window into a midpoint of a spatially and temporally extended process of transition from the world of the living to the world of the dead.

\section{Acknowledgements}

An earlier version of this paper was presented at the $53^{\text {rd }}$ annual meeting of the Institute of Andean Studies in Berkeley, CA, in January 2013. Many thanks to John Janusek, Victor Plaza, Carlos Lémuz, Kelly Knudson, Ryan Williams and the town of Qhunqhu Likiliki. We also thank the Unidad Nacional de Arqueología de Bolivia. This paper also benefited greatly from conversations with Wendy Ashmore, Tom Patterson, Arik Ohnstad, Andy Roddick, Erik Marsh, Randi Gladwell, Misty Bastian and Mary Ann Levine. We would also like to thank Emma 
Pomeroy and a second, anonymous reviewer for their excellent comments. This research was supported by a University of California, Riverside Humanities Research Grant and a Sigma Xi, Grant-in-Aid of Research to SCS. SCS would also like to thank Franklin \& Marshall College for its support through the Junior Faculty Research Leave programme. This work was also supported by grants from the following institutions to John Janusek: the National Science Foundation (BCS-0514624), the Curtiss T. \& Mary G. Brennan Foundation, the National Geographic Society (Scientific Field Research Grant, 7700-04), the Howard Heinz Endowment for Archaeological Research, and Vanderbilt University. We thank these institutions for their generous support. Any errors remain our responsibility.

\section{References}

ADAMS, R.L. \& S.M. KING. 2011. Residential burial in global perspective, in R.L. Adams \& S.M. King (ed.) Residential burial: a multiregional exploration (Archeological Papers of the American Anthropological Association 20): 1-16. Arlington (VA): American Anthropological Association.

ArNold, D.Y. \& C.A. Hastorf. 2008. Heads of state: icons, power, and politics in the ancient and modern Andes. Walnut Creek (CA): Left Coast.

Ashmore, W. \& P.L. Geller. 2005. Social dimensions of mortuary space, in G.F.M. Rakita, J.E. Buikstra, L.A. Beck \& S.R. Williams (ed.) Interacting with the dead: perspectives on mortuary archaeology for the new millenium: 81-92. Gainesville: University Press of Florida.

BANDY, M.S. 2005. Trade and social power in the southern Titicaca basin Formative, in K.J. Vaughn, D. Ogburn \& C.A. Conlee (ed.) Foundations of power in the Prehispanic Andes (Archeological Papers of the American Anthropologial Association 14): 91-111. Arlington (VA): American Anthropological Association.

BANDY, M.S. \& C.A. HASTORF (ed.). 2007. Kala Uyuni: an early political center in the southern Lake Titicaca basin (Contributions of the University of California Archaeological Research Facility 64). Berkeley: Archaeological Research Facility, University of California, Berkeley.

BERMANN, M. 1994. Lukurmata: household archaeology in Prehispanic Bolivia. Princeton (NJ): Princeton University Press.

BLOM, D.E. \& J.W. JANUSEK. 2004. Making place: humans as dedications in Tiwanaku. World Archaeology 36: 123-41. http://dx.doi.org/10.1080/ 0043824042000192623

Blom, D.E., J.W. Janusek \& J.E. Buikstra. 2003. A re-evaluation of human remains from Tiwanaku, in A.L. Kolata (ed.) Tiwanaku and its hinterland: archaeology and paleoecology of an Andean civilization. Volume 2: urban and rural archaeology: 435-49. Washington, D.C. \& London: Smithsonian Institution Press.
Browman, D.L. 1978. Toward the development of the Tiahuanaco (Tiwanaku) state, in D.L. Browman (ed.) Advances in Andean archaeology: 327-49. The Hague \& Paris: Mouton. http://dx.doi.org/10.1515/9783110810011.327

Buikstra, J.E. \& D.K. Charles. 1999. Centering the ancestors: cemeteries, mounds, and sacred landscapes of the ancient North American midcontinent, in W. Ashmore \& A.B. Knapp (ed.) Archaeologies of landscape: contemporary perspectives: 201-28. Malden \& Oxford: Blackwell.

Dillehay, T.D. (ed.). 1995. Tombs for the living: Andean mortuary practices. Washington (DC): Dumbarton Oaks Research Library and Collection.

DomAnSKA, C. \& J.W. JANUSEK. 2008. Bioarchaeology and an early death cult in the Bolivian Andes. Poster presented at the Society for American Archaeology $73^{\text {rd }}$ Annual Meeting, 26-30 March 2008, Vancouver.

Gasco, A.V. \& E.J. Marsh. 2013. Hunting, herding, and caravanning: osteometric identifications of camelid morphotypes at Khonkho Wankane, Bolivia. International Journal of Osteoarchaeology. http://dx. doi.org/10.1002/oa.2331

HASTORF, C.A. 2003. Community with the ancestors: ceremonies and social memory in the Middle Formative at Chiripa, Bolivia. Journal of Anthropological Archaeology 22: 305-32. http://dx.doi.org/10.1016/S0278-4165(03)00029-1

- 2005. The Upper (Middle and Late) Formative in the Titicaca basin, in C. Stanish, A.B. Cohen \& M.S. Aldenderfer (ed.) Advances in Titicaca basin archaeology, I: 65-94. Los Angeles (CA): Cotsen Institute of Archaeology.

Hu, D. 2011. Analysis de los artefactos líticos, in Excavaciones en Kala Uyuni: informe de la temporada 2009 del Proyecto Arqueológico Taraco: 102-22. Report prepared for the Unidad Nacional de Arqueologia de Bolivia, La Paz.

ISBELL, W.H. 1997. Mummies and mortuary monuments: a postprocessual prehistory of Central Andean social organization. Austin: University of Texas Press.

JanuseK, J.W. 2008. Ancient Tiwanaku. Cambridge: Cambridge University Press. 
- 2009. Centralidad regional, ecologia religiosa y complejidad emergente durante el periodo Formativo en la cuenca del Lago Titicaca, in P. Kaulicke \& T.D. Dillehay (ed.) Procesos y expresiones de poder, identidad, y orden tempranos en Sudamerica: 23-51. Lima: Fondo Editorial, PUCP.

- 2013. Jésus de Machaca before and after Tiwanaku: a background to recent archaeology at Khonkho Wankane and Pukara de Khonkho, in A. Vranich \& A.R. Levine (ed.) Advances in Titicaca basin archaeology, II: 7-22. Los Angeles (CA): Cotsen Institute of Archaeology.

JanuseK, J.W., A.T. OHNSTAD \& A.P. Roddick. 2003. Khonkho Wankane and the rise of Tiwanaku. Antiquity 77(296) Project Gallery. Available at: http://antiquity.ac.uk/projgall/janusek/janusek.html (accessed 5 June 2014).

Janusek, J.W., A.P. Roddick \& M. Pérez Arias. 2005. El Compuesto K1 y su vecinidad (Sector 6), in J.W. Janusek (ed.) Khonkho Wankane: primer informe preliminar del Proyecto Arqueológico Jach'a Machaca: 123-40. Report prepared for the Viceministry of Culture and the Dirección Nacional de Arqueología, La Paz.

Kingery, W.D., P.B. Vandiver \& M. PricketT. 1988. The beginnings of pyrotechnology, part II: production and use of lime and gypsum plaster in the Pre-Pottery Neolithic Near East. Journal of Field Archaeology 15: 219-44.

http://dx.doi.org/10.2307/530304

KNOBLOCH, P.J. 2000. Wari ritual power at Conchopata: an interpretation of Anadenanthera colubrina iconography. Latin American Antiquity 11: 387-402. http://dx.doi.org/10.2307/972003

KNUDSON, K. Forthcoming. Isotope analyses and the movement of humans and camelids in Machaca, in J.W. Janusek (ed.) Early complexity in the south-central Andes: Khonkho Wankane and its hinterland. Los Angeles (CA): Cotsen Institute of Archaeology.

Kolata, A.L. (ed.). 2003. Tiwanaku and its hinterland: archaeology and paleoecology of an Andean civilization. Washington (DC): Smithsonian Institution Press.

LAUDERMILK, J.T. 1932. Concerning quicklime burial. American Journal of Police Science 3: 59-63. http://dx.doi.org/10.2307/1147292

LECHTMAN, H. 1984. Andean value systems and the development of prehistoric metallurgy. Technology and Culture 25: 1-36. http://dx.doi.org/10.2307/3104667

Llagostera M., A. 1995. Art in the snuff trays of San Pedro de Atacama (northern Chile), in P. Dransart (ed.) Andean art: visual expression and its relation to Andean beliefs and values: 51-77. Aldershot: Avebury.
MARTIUS, K.F.P. vON. 1876. Flora Brasiliensis, enumeratio plantarum in Brasilia hactenus detectarum: quas suis aliorumque botanicorum studiis descriptas et methodo naturali digestas partim icone illustratas. Munich \& Leipzig: R. Oldenbourg.

NúÑEz Atencio, L. \& T.D. Dillehay. 1995 [1979]. Movilidad giratoria, armonía social y desarrollo en los Andes meridionales: patrones de tráfico e interacción económica. Antofagasto: Universidad Católica del Norte.

OHnSTAD, A. 2007. Investigaciones en áreas periféricas de los montículos de Wankane y Putuni, in J.W. Janusek \& V. Plaza Martinez (ed.) Khonkho e Iruhito: tercer informe preliminar del Proyecto Jach'a Machaca (investigaciones en 2006): 141-86. Report prepared for the Viceministry of Culture and the Dirección Nacional de Arqueología, La Paz.

- 2011. La escultura Prehispánica de Khonkho Wankane, Jesús de Machaca, Bolivia. Nuevos Aportes 5: 119-42.

- 2013. The stone stelae of Khonkho Wankane: inventory, brief description, and seriation, in A. Vranich \& A.R. Levine (ed.) Advances in Titicaca basin archaeology, II: 53-66. Los Angeles (CA): Cotsen Institute of Archaeology.

Ohnstad, A. \& J.W. JAnuseK. 2007. The development of 'Tiwanaku style' out of the ideological and political-economic landscapes of the Formative period Titicaca basin. Paper presented at the Southern Andean Iconographic Series: a Colloquium in Pre-Columbian Art and Archaeology, Santiago de Chile, March 2007.

PARKer PEARson, M. 1999. The archaeology of death and burial. College Station: Texas A\&M Press.

Portugal Zamora, M. 1955. El misterio de las Tumbas Wankani. Khana 11-12: 51-67.

PROCTOR, H.R. 1903. The principles of leather manufacture. London: E. \& F.N. Spon.

RAKITA, G.F.M. \& J.E. BUIKSTRA. 2005. Introduction, in G.F.M. Rakita, J.E. Buikstra, L.A. Beck \& S.R. Williams (ed.) Interacting with the dead: perspectives on mortuary archaeology for the new millennium: 1-11. Gainesville: University Press of Florida.

Schotsmans, E.M.J., J. Denton, J. Dekeirsschieter, T. IVANEANU, S. LEENTJES, R.C. JaNAWAY \& A.S. WILSON. 2012. Effects of hydrated lime and quicklime on the decay of buried human remains using pig cadavers as human body analogues. Forensic Science International 217: 50-59. http://dx.doi.org/10.1016/j.forsciint.2011.09.025

SMITH, S.C. 2009. Venerable geographies: spatial dynamics, religion, and political economy in the prehistoric Lake Titicaca basin, Bolivia. Unpublished PhD dissertation, University of California, Riverside. 
- 2013. Late Formative period spatial organization at Khonkho Wankane, Bolivia, in A. Vranich \& A.R. Levine (ed.) Advances in Titicaca basin archaeology, II: 23-44. Los Angeles (CA): Cotsen Institute of Archaeology.

Smith, S.C. \& M. PÉrez Arias. 2007. Excavaciones en el Sector 12 (Compuesto 3, Parte Sur), in J.W. Janusek \& V. Plaza Martinez (ed.) Khonkho e Iruhito: tercer informe preliminar del Proyecto Jach'a Machaca (investigaciones en 2006): 114-39. Report prepared for the Viceministry of Culture and the Dirección Nacional de Arqueología, La Paz.

STAnish, C. 2003. Ancient Titicaca: the evolution of complex society in southern Peru and northern Bolivia. Berkeley: University of California Press. http://dx.doi.org/10.1525/california/ 9780520232457.001 .0001
Torres, C.M. \& W.J. ConkLIN. 1995. Exploring the San Pedro de Atacama/Tiwanaku relationship, in P. Dransart (ed.) Andean art: visual expression and its relation to Andean beliefs and values: 78-108. Aldershot: Avebury.

Torres, C.M. \& D.B. RePKE. 2006. Anadenanthera: visionary plant of ancient South America. Binghamton (NY): Haworth.

Whitley, J. 2002. Too many ancestors. Antiquity 76: 119-26.

ZOVAR, J.M. 2006. Excavaciones en Sector 9, Compuesto K2 y su vecinidad, in J.W. Janusek \& V. Plaza Martinez (ed.) Khonkho Wankane: segundo informe preliminar del Proyecto Arqueológico Jach'a Machaca: 127-41. Report prepared for the Viceministry of Culture and the Dirección Nacional de Arqueología, La Paz.

Received: 11 November 2013; Accepted: 23 December 2013; Revised: 5 February 2014 